\title{
The Role of Store Layout and Visual Merchandising in Food Retailing
}

\author{
Ivana Štulec, Ph. D. \\ Faculty of Economics and Business, University of Zagreb \\ istulec@efzg. hr \\ Kristina Petljak, Ph. D. \\ Faculty of Economics and Business, University of Zagreb \\ kpetljak@efzg.hr \\ Anja Kukor, M. A. \\ The synchronized swimming club Medveščak \\ anja.kerkez@gmail.com
}

\begin{abstract}
Literature proposes a number of store attributes as potentially significant factors affecting customers' evaluation of retailer's image, store loyalty and overall satisfaction, such as merchandise assortment and quality, service in general, personnel, store layout, convenience, cleanliness and atmosphere. Successful and profitable retailers use effectively each and every square meter of the retail space, both in the store and in the warehouse. Since retail space is costly, space management is gaining strategic importance in retailing. Appropriate store floor plans, location of certain merchandise categories, levels of inventory and visual displays are crucial factors of proper use of retail space. Misuse of retail space can be detrimental to retailer's bottom line as it can result in difficulties in orientation of customers in the store, their shorter stay in the store, consequentially lower sales and possible loss of customers. It is hypothesised that effects of poor space management are even more pronounced in retail formats that incorporate self-service as a selling method with food retailers being especially at risk because in a setting where consumers can find identical merchandise in more than one store, layout and presentation become key differentiating factors. An empirical study is conducted as to determine the role of food store layout and visual merchandising compared to other store attributes in achieving customer satisfaction and to define preferable large food store layout among consumers. Research results imply that retailers need to create stimulating atmosphere and appealing layout in order to trigger consumer's buying decision.
\end{abstract}

Keywords: store layout, visual merchandising, retail space management, food retailing.

\section{Introduction}

Location has long been cited as a prime reason for choosing a certain retail store. In addition, literature proposes a number of other store attributes as potentially significant factors that affect customers' evaluation of retailer's image, store loyalty and overall satisfaction, such as merchandise assortment and quality, service in general, personnel assistance, store layout, convenience of shopping, cleanliness and atmosphere. Today's customers present a true challenge for retailers as they are faced with less time, less money and more demands. It is why retailers should learn how to meet their needs and turn them into loyal customers. Retailers' most valuable asset is retail space and they should learn to manage it in a way to maximize sales per square metre. In order to achieve this ultimate goal they should learn first how to use visual 
merchandising techniques to attract customers to the store and offer them unique and enthusiastic shopping experience. Customers that feel amused and intrigued will spend more time in the store, browse through different departments of the store and consequently purchase more merchandise. If customers feel that their shopping trip was smart, conductive and hassle free, they will want to repeat that experience. On the other hand, if they are in any way irritated by some of the store attributes or if visual presentation does not meet their expectations, they may choose to leave the store prematurely, not to enter at all or not to come ever again.

The importance of visual merchandising has long been recognised and much studied in fashion retailing which is somewhat expected given that is well-known that people tend to buy more when are in good mood because they are prone to selfrewarding (Underwood et al. , 1973) and since clothes and accessories are category of merchandise that is tightly connected to the self-image customers project about themselves (Jain et al. , 2014). Through effective visual merchandising techniques retailers are trying to get their customers in the good mood, whereas high margins in fashion retailing justify and cover for high costs of visual merchandising.

Visual merchandising in food retailing, on the other hand, remains rather understudied and under-practiced since small margins in food category often require tight costs control which leads to negligence of visual merchandising. At the same time, food stores are in particular need of good store design and good visual merchandising since they sell majority of merchandise that is easily available in other stores and heavily rely on self-service. In such circumstances it becomes both a necessity and extremely hard to differentiate itself from competition. Store design is an especially difficult task when it comes to grocery and food stores because consumers generally perceive grocery and food shopping as a task and not as an experience. When headed for grocery shopping, majority of customers do not wish for an experience but aim to make a smart, hassle free and conductive purchase in shortest time possible. Yet, at the same time, all customer have a minimum they expect to be delivered by a retailer, regardless is it about product availability and quality, personnel assistance, store cleanliness, lighting or scents. Even if customers are not looking for a shopping experience, they sure will notice the lack of one. It is the task of a retailer to know his customer needs and to excel them. Those who succeed will gain competitive advantage.

The role of store layout and visual merchandising in food retail forced itself as an understudied subject. The purpose of the subject was to explore how certain store attributes affect customer buying behaviour and store traffic. Following research questions emerged:

How do customers rank factors of store choice by importance?

How do customers assess importance of certain in-store attributes?

What can irritate customers at the very point-of-sale?

Which is the preferable food store layout from the perspective of consumers?

How do consumers' demographic characteristics affect their perception of certain store attributes?

The rest of the paper is organised as follows. Section two provides theoretical background on the store design, layout and visual merchandising. Section three gives a review of studies on the effect of store attributes and visual merchandising on customer buying behaviour. Section four explains design of our research and methods used in data analysis. Section five provides research findings and discussion of results. Section six concludes on theoretical and empirical insights.

\section{On the store design and visual merchandising}

Retailers are giving increasing attention to visual merchandising techniques to provide positive mood for consumers as to turn shoppers into buyers and to increase store loyalty and repurchase intention. Literature proposes several definitions of visual merchandising. New Oxford Dictionary of English (Pearsall \& Hanks, 1999) defines it as "an activity of promoting the sale of goods, especially by their presentation in the retail stores". Banarjee \& Yadav (2012) add that visual merchandising combines the product, environment and space into a stimulating and engaging exterior and interior that create positive 
image of a business and results in attention, interest, desire and action on the part of the customer. Levy \& Weitz (2007) define visual merchandising as presentation of a store and its merchandise in ways that will attract the attention of potential customers. Balgaonkar et al. (2014) see visual merchandising as the art and science of displaying and presenting product on the sales floor and in the windows with the purpose to increase store traffic and sales volume.

Broadly speaking, visual merchandising can be defined as everything the customer sees, both exterior and interior. Exterior should be designed in a way that reflects interior and ambiance of the store, luring potential customer to enter the store. Exterior refers to outdoor parking and/or garage, landscaping, entry and window displays. Store exterior gives potential customers first information about the store. Entry is the only part of the store that every consumer walks through, given that there is only one entry to the store as it usually is. It is why entry should be designed with special care, not to deter customer from entering. Entry should be designed in a way it provides sufficient space for hassle free movement. Parking lots should be wide enough and placed near entry as possible. Socially responsible retailers will provide special parking spaces for handicapped and families with small children. Landscaping especially comes to fore when considering high-end stores and shopping malls. Aesthetically designed garbage bins and benches, creative paving and maintained grass and plants are an example of good landscaping. Window displays are of special importance because it is what customers see first. Window display should be simple but informative and in accordance with the store offering. Its task is to pull customers inside the store and to differentiate the store from competing stores. Well-designed window display can result in higher impulse buying, presuming that store interior will not deter shopper from making a purchase. Interior refers to store layout and visual features in the store such as store signage, fixtures, props, posters etc. According to Banerjee \& Yadav (2012) interior presentation is crucial in the first thirty seconds of the customer's visit to the store since it decides whether the customer will stay to browse and possible buy or will he leave the store. If window display is not a good presentation of the store offering and ambiance, the customer will most likely leave in these thirty seconds. If window display is a good presentation of the store offering and ambiance, it is the task of store layout and visual features to allow customers to easily and rather quickly find merchandise they need. Store signage provides basic and significant information to the customers regarding prices, category placement, discounts, promotions, tasting etc. The role of props is to highlight certain merchandise inside the store and add to visual presentation of the store. Good visual merchandising will attract customers inside the store, and once they are in the store, good visual merchandising will draw them to different sections of the store. The store which has good visual merchandising will keep the customer in for a longer time thus leading to the purchase of a product (Kerfoot et al. , 2003). The visual merchandising display can guide the customer throughout the store without the help of the store staff (Kiran \& Mridula, 2015). It is why visual merchandising is often cited as a silent salesperson.

When designing a store, retailer's main objectives are to implement its strategy, influence customer buying behaviour, provide flexibility, control design and maintenance costs and meet legal requirements (Levy \& Weitz, 2007). The art and science of point-of-sale design and space management are increasingly gaining in importance and have far long overcome the needs of only retail. Today, smart point-of-sale design is crucial factor of successfulness for every service business including not only retail stores and shopping malls, but banks, casinos, bakeries, perfumeries and doctors' offices as well. Whenever a customer has more than only one option, retailers and other service providers should learn to please his senses.

Store layout and visual merchandising are of particular importance in retail formats that employ self-service since staff assistance is limited in such stores, whereas in specialty stores that offer full staff assistance, good store layout can add to image of the store. Literature proposes several basic store layouts or floor plans. (1) The counter store layout appears in stores where all the selling is done over the counter and is incompatible with the modern idea of self-service (Ebster \& Garaus, 2015). Nowadays, counter store layout is still present in stores that because of sanitary standards, theft hazard, small space and high staff assistance cannot employ self-service such as bakeries, pastry shops, jewellery stores, small convenience stores, newsstands and exclusive perfumeries. Following store layouts support the idea of self-service. (2) The forced-path layout forces the shopper to take a certain route through the store (Ebster \& Garaus, 2015) in order to introduce him to as many merchandise displayed in the store as possible. Furniture and home accessories stores often employ this type of layout. However, retailers should keep in mind that the goal is to keep customer intrigued and entertained in the store as long as possible, and not just as long as possible. It is why forced-path layouts should be accompanied by visible shortcuts that allow customers to exit prematurely. Retailers that do not offer its customers an alternative path are jeopardising their coming back to the store. (3) The grid layout has parallel aisles with merchandise on shelves on both sides of the aisles (Levy \& Weitz, 2007). A grid layout offers several advantages as it allows customers to shop quickly, it 
simplifies inventory control, floor space is used efficiently and standard fixtures can be used to display the merchandise (Ebster \& Garaus, 2015). Waters (n/a) further mentions two store layouts that can be considered as grid layouts: straight layout and diagonal layout. Grid layout is one of most economical layouts and is traditionally favoured by food stores, drug stores, and hardware stores. (4) The racetrack layout, often called loop layout, provides major aisle that loops around the store to guide customer traffic around different departments within the store (Levy \& Weitz, 2007). The racetrack layout facilitates the goal of luring customer to browse through different departments and thus encourages impulse buying. Racetrack layout is often favoured by apparel retailers. Ebster \& Garaus (2015) further argue that racetrack layout can be achieved within any other layout. (5) The free-form layout arranges fixtures and aisles in an asymmetric, free-flow pattern (Ebster \& Garaus, 2015; Levy \& Weitz, 2007). Main advantage of free-form layout is that it enhances the atmosphere of the store and the shopping experience of the customer, shoppers are encouraged to browse through the store and are more likely to make impulse purchase. Ebster \& Garaus (2015) further divide free-form layout into the boutique layout, star layout and arena layout. Boutique layout has a look of a shop-in-the-shop and is often utilised in apparel and fashion retailing and specialty stores where each shop-in-the-shop is devoted to certain merchandise category or brand manufacturer. Star layout arranges aisles in a star-like pattern creating thus luxurious feel of a store, which is why is often used in perfumeries, high-end fashion stores and jewellery stores. Arena layout slightly resembles amphitheatres. Shelves placed in the back of the store are often taller than the ones placed in the front, or can be even placed on a pedestal. Arena layout is mostly favoured by book stores and record stores. Waters (n/a) further mentions angular and geometric layouts which can be considered as free-form layouts. (6) The combined or mixed layout which is a result of combining different store layouts. Combined store layouts are mostly applicable in large stores formats that sell different merchandise categories such as hypermarkets and supermarkets, where food categories are presented through traditional grid layout which is combined with free-form layout for non-food merchandise. Confronted with ever increasing competition and more and more demanding customers, retailers of today need to find new sources of differentiation as to excite customers and excel the competitors. Designing new alluring and exciting layouts that will enhance shopping experience for its customers becomes a must for supermarkets and hypermarkets and other predominantly food stores that sell merchandise that is easily available in competitor stores as well.

When planning and designing the food store layout, several principles can be noticed (Vučijak, 2007). Firstly, food retailers often use sensory stimuli to create an appealing feel of a store. It is why bakery products, flowers and fresh fruit and vegetables are often placed at the very entrance of the store. Secondly, fast moving consumer goods that are bought and consummated regularly on a daily basis are often placed in the back of the store in order to make consumers walk through the entire store and possibly buy more merchandise than planned. Third design principle refers to the direction of movement of customers through the store. Given that majority of customer tend to move clockwise, food stores often place entries on the right, enticing thus customers to walk through the entire store. According to forth principle, the main aisle leads to the so called heart of the store where the majority of merchandise is sold. Mrvica Mađarac \& Stojanovic (2009) mention yet another principle that regards positioning of the merchandise on the shelves. In that context, planograms as visual presentations of shelf space allocation became an indispensable tool of modern retail space management. Bottom shelves are reserved for products that are in their declining phase, big packages and everyday necessities like oil, sugar, flour etc. that do not need better positioning since consumers will make an effort to find them anyway. Top shelves are reserved for luxury and pricey products as to minimise the possibility of damage. Middle shelves in the eye level are reserved for top selling and top brand products. Brand manufacturers are often obliged to pay fee for prime eye level positions. Novelty in the merchandise positioning are so called kid's shelves that hold toys and candies and are placed in the lower half in the kid's eye level. Food Marketing Institute (2015) cites that household with children have almost 60 per cent higher weekly grocery expenses than household without children, whereas findings of Coughlin \& Wong (2003) indicate that more and more kids participate with their parents in grocery shopping and that kids notice signs in the store as well as promotions and packaging innovations. Aghazadeh (2005) divides principles of store layout into principles of circulation, coordination and convenience. The principle of circulation provides an arrangement that facilitates customer traffic flow through the store and encourages circulation throughout the different departments. The principle of coordination deals with placement of merchandise within the store in order to create good will, furnish subject matter to customer and promote sales. Goods should be combined with space in such a way to remind of, suggest and create customer needs. The principle of convenience is arranging items to furnish a high degree of convenience to the customer and personnel.

A well-planned retail store layout allows a retailer to maximize the sales for each square metre of the allocated selling space within the store. Efforts to gain sustainable comparative advantage through unique store layout become more tense than 
ever before which can be evident from Apple's legal action to trademark the layout of its retail stores (Oliver, 2014). At the same time, given that well-planned and well-designed stores lure customers to make unplanned and possibly redundant purchase, an ethical issue can be raised regarding the goals of retail space management.

\section{Literature review on the effect of store attributes on customer buying behaviour}

Because 68 per cent of buying decisions are unplanned, retailers need to understand the effectiveness of point-of-purchase marketing efforts (Stahlberg \& Maila, 2010). Good point-of-purchase marketing efforts can result in appealing store atmosphere which turns shoppers into buyers and increases time customers spend in the store, as well as their repurchase intentions. Mohan et al. (2013) found that store environment drive impulse buying through positive affect and urge. Results of Banerjee \& Yadav (2012) show that high impulse products are generally being placed at the checkout counters, in eye level racks and window displays.

The effects of store atmosphere created through visual merchandising and store attributes on consumer buying behaviour have been much studied in textile, apparel and fashion retailing (Ballantine et al. 2015; Jain et al. , 2014; Clarke et al. , 2012; Law et al. , 2012; Mower et al. , 2012; Parsons, 2011; Kerfoot et al. , 2003), plant retailing (Huddleston et al. , 2015) and toy retailing (Kiran \& Mridula, 2015) which can be reasoned by high margins that justify for high costs of visual merchandising. Food retailing, on the other hand, remains rather understudied. Small margins in food category often require tight costs control and lead to negligence of visual merchandising. Simultaneously, food stores are in particular need of good store design and good visual merchandising since they sell majority of merchandise that is easily available in other stores and heavily rely on self-service. In such circumstances it becomes both a necessity and extremely hard to differentiate itself from competition.

Huddleston et al. (2015) found that providing signs with product information but without product price elicits higher likelihood to buy than providing signs with price. Furthermore, the authors found a positive relationship between visual attention to price on the display sign and likelihood to buy, but an inverse relationship between visual attention to information and likelihood to buy.

Kiran \& Mridula (2015) found that ability to touch, explore and try products lead to higher customer satisfaction. Retailers offering electronic devices and gadgets have gone a step further and designed so-called experience store formats that allow customers to try products before they buy them (Jones et al. , 2010) which can have a highly positive impact on purchase intention since immersive technology is being offered. Findings of Clarke et al. (2012) reveal that it is not just tangible things that can affect a shopper's experience, but store traits such as smell, lighting and presence of ownermanager can also influence a consumer's experience. Ballantine et al. (2015) further argue that store attributes cannot be observed independently one from another and set a holistic model that shows that atmospheric cues encountered in a retail environment contribute to the creation of a retail experience in different stages of the buying process, from the initial store evaluation to the intention to purchase. Likeable and appealing visual display is not itself a guarantee that a purchase will be made, but it does make it four times more likely (Kerfoot et al. , 2003). Parsons (2011) found that interactions between sensory stimuli have a significant effect on fashion shoppers and that small change in stimuli levels can revitalise and increase that effect. At the same time, results show that fashion retailers are still not as much differentiated in their use of sensory stimuli as they could be to achieve the responses they expect.

It is not only important how to present merchandise in the store, but in what quantity as well. Results of Smith \& Burns (1996) suggest that merchandise techniques can affect consumers' perceptions of prices. More precisely, an aisle comprising a smaller number of stock-keeping units in correspondingly greater quantity of each item will create an illusion of a lower price than will an aisle comprising a greater number of stock-keeping units in correspondingly smaller quantity of each item.

In addition to in-store atmosphere, results of Mower et al. (2012) indicate that exterior atmospherics, namely window display and landscaping, influence consumers' liking of store exterior, mood and patronage intentions. Further on, results of Law et al. (2012) imply that customers have two points of view when evaluating visual store displays, meaning that the effect of visual merchandising relies on whether customer seeks to satisfy its hedonic or utilitarian needs. Since research is conducted in intimate apparel category among female shoppers, the utilitarian aspect relates to the actual needs of 
consumers, such as garment deterioration, seasonal changes and occasions whereas the hedonic aspect finds that the perceived female image governs consumer interpretation and acceptance of visual displays. Jain et al. (2014) found that consumers may be more inclined to purchase products when the window display makes them feel good. These windows should provide consumers with social, functional, hedonic and image-related benefits, offering information on trends and core product attributes while simultaneously helping consumers to create positive fantasies about their lives.

Retailer's task is to deliver an experience a shopper will want to repeat. The role of store design is to provide information that will assist the customer along the way (Soars, 2003). However, since customers can easily get overwhelmed with stimuli and oversaturated with size and in-store information, retailers should take care that more is not always better. Too much signage and propping combined with confusing traffic patterns are often cited as deadly sins of visual merchandising (Anonymous, 2010). When it comes to visual merchandising, what not to do is as important as what to do.

Nowadays, time is one of the most scarce resources so majority of customers seek to fulfil their shopping and purchase needs in shortest time possible. Even if customers are intended to browse and shop, not necessarily buy, they will stay in the store only as long as they feel entertained. Customers can easily get irritated when they fell lost and not in control. Some may decide to leave the store without making a purchase, while others may decide not to shop in that store ever again. Convenience and time-saving gain in importance especially when considering grocery and food shopping because people tend to perceive grocery shopping as a task rather than as an experience. Store layout helps to save time if it is not too spread out and if items on special offer are aggregated in promotional areas such as end caps. Consumers can also save time if display is logically organised and if store offers services that allow fast check-out such as self-scanning and self-check-out. As other reasons for choosing a particular grocery shop customers mention, named in the order of importance: quality of shopping experience, low prices and trust and loyalty to the retailer (Bellini \& Cardinali, 2015). However, authors' findings further indicate that customers generally do not perceive significant difference between grocery retailers, implying that retailers should work on their differentiation in terms of meeting customer needs. In addition, study of Narayan \& Chandra (2015) distinguishes seven factors affecting customers' preference of a grocery store: convenience of shopping, personnel assistance, store ambience, brand image, proximity, value-added services and affordable prices.

The goal and challenge of visual merchandising in food retailing is not only to attract customers into the store, but to induce them to browse through the store, visit as many departments of the store as possible, stay as long as possible, buy as many as possible, leave satisfied and come again. Those retailers who succeed will gain a comparative advantage.

\section{Research design and methodology}

For the purpose of our study, a highly structured online survey was conducted among consumers in Croatia. The questionnaire was comprised as a mixture of close-ended and rating scale questions concerning demographic characteristics of respondents and their perception of store attributes and atmosphere. Respondents were additionally presented with three alternative store layouts observed in large grocery stores (supermarkets) of leading Croatian retail chain and asked to assess their liking of each layout. Questionnaires were distributed online through social media which allowed for rather quickly and affordable data collection. During the period of two months a total of 199 responses were collected. In results analysis, descriptive and parametric statistics were used, namely t-test and analysis of variance (ANOVA) for mean comparison between groups.

\section{Results analysis and discussion}

Total of 199 valid responses were collected. Table 1 outlines sample characteristics regarding the demographics. Majority of respondents were female, age between 19 and 45, employed.

Respondents were asked to rank seven factors of store choice by importance with 1 being "most important" and 7 being "completely unimportant". Table 2 gives results review. Majority of respondents gives highest importance rank to merchandise quality, price and service quality which can be explained as a consequence of economic crisis due to which consumers ask for highest value-for-money. It comes as a surprise that store location is not as important to our consumers as literature often cites witch can be explained with high coverage of retail space square metres per capita. Store design and working hours arose as least important factors. Probable explanation for low importance of store design in store choice 
could be because customers are task oriented when shopping for groceries and possibly unaware of its effect. Working hours are not perceived as an important factor since stores in Croatia are generally open seven days a week, minimally 12 hours a day.

Next, respondents were asked to assess importance of certain store attributes on a scale 1 do 5 (1 being "completely unimportant", 2 "unimportant", 3 "indifferent", 4 "important" and 5 "extremely important"). Based on the average assessments of attributes importance (Table 3), findings indicate that customers value the most clearly displayed merchandise prices, which goes hand in hand with previous finding that prices are one of the main factors customer take into consideration when choosing a grocery store. Store cleanliness, visibility of merchandise and layout that allows practical traffic flow arise as following most important store attributes. Aesthetics of store design, music and lighting, shelf height and presentation of new products on hot spots come as least important attributes which can be again reasoned by the fact that grocery shopping was studied.

Many consumers when asked about store attributes they find important, think only about the attributes they expect retailers to excel and overlook the attributes they consider to be pure minimum. It is why consumers were asked directly to assess level of irritation by certain negative store attributes on a scale 1 to 5 ( 1 being "not irritant at all", 2 "not irritant", 3 "indifferent", 4 "irritant" and 5 "completely irritant"). Results are given in Table 4. It can be seen that customer most easily get irritated by unhelpful, impolite and uneducated personnel even though large food store format relies heavily on self-service. Visibility of prices again takes the high rank among the attributes. Customers also get easily irritated by crowd in the store and loud music. The weight of irritation and dissatisfaction triggers can be verified by the following finding that $93.9 \%$ of respondents were provoked, at least once, to switch to another store because of these negative attributes $-46.7 \%$ rarely and $47.2 \%$ often.

Respondents were presented with three alternative layouts observed in large grocery stores (supermarkets) of leading Croatian retail chain and asked to assess their liking of each layout on the scale 1 to 5 ( 1 being "do not like at all", 2 "do not like", 3 "indifferent", 4 "like" and 5 "like very much"). Layout schemes are given in Appendix. All three layouts can be characterised as mixed layouts combined of loop and grid layout. Loop layout provides a round main aisle that loops around the heart of the store where majority of merchandise is sold. What differs is the product categories placed in the centre of the loop and along the path. Yet another similarity is that all three layouts have entry at the right side of the floor plan, embracing thus rule of thumb that majority of customers move counter-clockwise. Layout 1 places dry food and seasonal merchandise in the middle section, whereas loop start with floral section on the right, followed by deli and fresh fruits and vegetables (produce). In the back of the store, dairy and bakery products, meat and fish are positioned. Loop continues with household supplies, frozen food and wine. Special price products are placed near the cashiers. Layout 2 places dry food, seasonal merchandise and special price products in the middle section with special price products closest to the cashiers and visible from outside the store. Loop starts with floral section on the right, followed by winery, frozen foods and household supplies. Deli section is placed in the back of the store. Loop continues with dairy, fresh meat and fish and bakery. Fresh fruits and vegetables section is placed near the cashiers and is visible from the outside. Layout 3 placed seasonal merchandise and special price products in the middle section with special price product close to the cashiers so they could be bought impulsively when waiting in line and visible from the outside. Loop starts with bakery on the right, followed by fresh fruits and vegetables, dairy and fresh meat and fish. Dry food and deli section are placed in the back of the store. Loop continues with household supplies and frozen food and ends with winery and floral section.

Results indicate that layout 3 distinguishes as the most preferable and likable layout with average assessment 3. 61, whereas layouts 1 and 2 are somewhat similarly assessed with grades 3.17 and 3. 14, respectively. First should be noticed that all three presented layouts got somewhat mediocre assessments implying that neither fully satisfies customers' needs with regard to functionality, convenience and practicality. All three layouts obey the practical rule to place high draw items around the periphery of the store as to increase traffic throughout the store. It can be argued that layout 3 is the preferable one because it succeeded to arrange merchandise categories in the most convenient way. From outside the store, customers are drawn by sensory stimuli: pleasurable sight of floral section and luring scent of freshly baked products. Products offered on special promotions are also observable from the outside which contributes to the store patronage. Winery and floral section are smartly positioned at the end of the loop, near the cashiers, as to minimise the hassle of handling delicate merchandise. 
Next, collected data were cross-tabulated as to explore whether respondents' demographic characteristics such as gender, age and working status are significantly associated with customers' assessments of store choice factors, store attributes and layouts. An independent-samples t-test was conducted to compare the mean assessment of importance of store choice factors between males and females and result show that females tend to give higher ranks to all factors except working hours, but difference is not statistically significant. Regarding the assessment of store attributes, an independent-samples t-test showed that statistically significant difference in assessments of store attributes between males and females appears only for "visibility of displayed merchandise" (Male: $M=3.71, S D=0$. 95; Female: $M=4.09, S D=0.78 ; t(197)=-2.887, p=0$. 004 two-tailed) and "shelf height" (Male: $M=3.07, S D=0$. 98; Female: $M=3.40, S D=0.90 ; t(197)=-2$. 322, p=0. 021 twotailed). Results indicate that females tend to assess importance of visibility of displayed merchandise and shelf height higher than males, whereas other store attributes show no statistically significant difference in assessments regarding the customer gender. Regarding the negative store attributes that irritate customers, an independent-samples t-test showed statistically significant difference in assessments between males and females for "impolite personnel" (Male: $M=4.53$, $S D=0.73$; Female: $M=4.74, S D=0.53 ; t(197)=-2.274, p=0.024$ two-tailed), "too high shelves" (Male: $M=3.19, S D=0.90$; Female: $M=3.51, S D=1.00 ; t(197)=-2.115, p=0.036$ two-tailed) and "no parking" (Male: $M=4.19, S D=0.90 ;$ Female: $M=3$. $37, S D=1.23 ; t(197)=2.254, p=0.025$ two-tailed). Results indicate that females get more easily irritated by impolite personnel and too high shelves, while males are more easily triggered by no parking. Other negative store attributes show no statistically significant difference in assessments between males and females. Likewise, males and females show no statistically significant difference when assessing different store layouts.

Next, series of one-way between-groups ANOVA tests were conducted as to explore whether age is statistically significant factor of buying behaviour. Regarding the store choice factors and store attributes, customer of different age groups show no statistically significant difference in importance assessments. On the other hand, results of one-way ANOVA show that age has statistically significant effect on level of irritation caused by following negative store attributes: "uneducated personnel" $[F(4,194)=2$. 828, $p=0.026]$, "crowd in the store" $[F(4,194)=2.710, p=0.031]$, "loud music" $[F(4,194)=4.480$, $p=0.002]$, "unattractive store design" $[F(4,194)=3.263, p=0.013]$ and "no parking" $[F(4,194)=2.525, p=0.042]$. Figure 1 shows mean assessments of statistically significant factors of irritations by age groups. It can be argued that older customers get more easily irritated by uneducated personnel, loud music and unattractive store design, which can be reasoned by their mature needs, whereas middle-aged consumers most easily get irritated by crowd in the store and no parking, which can be reasoned by their busy schedule and desire to complete the shopping task as soon as possible. Regarding the preference of presented store layouts, customers of different age show no statistically significant difference in their assessments.

Again, series of one-way between-groups ANOVA tests were conducted as to explore whether working status affects customer buying behaviour. Results indicate that customers of different working status show statistically significant difference in assessments only of following negative store attributes: "uneducated personnel" $[F(4,194)=2.452, p=0.047]$, "loud music" $[F(4,194)=4.238, p=0.003]$ and "unattractive store design" $[F(4,194)=4.150, p=0.003]$. Store layouts and other store attributes show no significant association with working status. Figure 2 shows mean assessments of statistically significant factors of irritations by working status groups. It can be seen that retirees get easily irritated by uneducated personnel and loud music, which can be reasoned by their age, whereas younger employed customers get easily irritated by unattractive store design, which can be reasoned by their higher purchasing power.

\section{Conclusion}

A number of stores attributes act as potentially significant factors that affect customers' evaluation of retailer's image, store loyalty, patronage and overall satisfaction. Today's retailers are challenged to maintain tight costs control while satisfying the needs of ever demanding customers at the same time. In order to achieve both goals, they are forced to utilize retail space to its maximum i. e. to maximise sales per square metre of retail space. To do so they need to create an attractive store design and enjoyable store atmosphere, so that customers would increase their spending which will in turn overcompensate for the costs of visual merchandising. Food stores are in special need of visual merchandising because they rely heavily on self-service and generally offer merchandise that can be easily bought in competing stores. At the same time, visual merchandising is still under-practiced and understudied in food stores as small margins do not justify for high costs of visual merchandising. An empirical study among Croatian consumers was conducted as to explore how store attributes affect customer buying behaviour when it comes to grocery and food shopping. Results indicate that Croatian 
consumers are price sensitive as they give higher importance to merchandise price that to visual attributes. Yet, at the same time, if their requirements regarding certain store attributes are not met, they do not hesitate to switch to another store. Impolite, uneducated personnel and poor price display stand out as most irritable negative store attributes. Customers' demographics such as gender, age and working status show statistically significant effect on some aspects of customer buying behaviour. Results are of great practical value as they imply to which attributes and activities store managers should put an extra effort and which is the preferable layout for large food stores.

Recommendations for further research relate to scope of research and research methodology. Scope of research should be broadened as it would be interesting to explore how other characteristics of respondents, for example average weekly grocery store spending and shopper type, affect their purchase intentions, satisfaction and overall shopping engagement. In-depth interviews should be conducted with the consumers that are responsible for household grocery shopping as to fully understand how are they perceiving certain store attributes, both positive and negative, and to explore which store layout would allow them maximum convenience and minimum confusion. Interviews could be accompanied by eye-tracking study as to further explore what customers actually notice in the store and what keeps their sight and attention for a longer time.

\section{References}

[1] Aghazadeh, S-M. (2005) Layout strategies for retail operations: A case study, Management Research News, 28 (10), 31-46.

[2] Anonymous (2010) 7 Deadly Sins of Visual Merchandising, Home Furnishings Business, 5 (2), 34.

[3] Balgaonkar, V. , Pabalkar, V. , Yelikar, R. R. (2014) Visual merchandising and purchase behaviour of youth: a cluster analysis, International Journal of Applied Services Marketing Perspectives, 3 (3), 1158-1164.

[4] Ballantine, P. W. , Parsons, A. , Comeskey, K. (2015) A conceptual model of the holistic effects of atmospheric cues in fashion retailing, International Journal of Retail \& Distribution Management, 43 (6), 503-517.

[5] Banarjee, S. Yadav, P. (2012) Analysis of visual merchandising: effect on consumer buying behaviour, International Journal of Retailing \& Rural Business Perspectives, 1 (2), 209-217.

[6] Bellini, S. , Cardinali, M. G. (2015) A Consumer Perspective on Grocery Retailers' Differentiation, International Business Research, 8 (8), 129-140.

[7] Clarke, D. W. , Perry, P. , Denson, H. (2012) The sensory retail environment of small fashion boutiques, Journal of Fashion Marketing and Management: An International Journal, 16 (4), 492-510.

[8] Coughlin, R. , Wong, T. (2003) The retail world from a child's perspective, Young Consumers, 4 (1), 3-8.

[9] Ebster, C. , Garaus, M. (2015) Store Design and Visual Merchandising: Creating Store Space That Encourages Buying, $2^{\text {nd }}$ ed. New York: Business Expert Press

[10] Food Marketing Institute (2015) Weekly Household Grocery Expenses 2015 [online]. Available at: http://www. fmi. org/research-resources/supermarket-facts/weekly-household-grocery-expenses-2014 (accessed February 4, 2016)

[11] Huddleston, P. , Behe, B. K. , Minahan, S. , Fernandez, R. T. (2015) Seeking attention: an eye tracking study of in-store merchandise displays, International Journal of Retail \& Distribution Management, 43 (6), 56-574.

[12] Jain, V. , Takayanagi, M. , Malthouse, E. C. (2014) Effects of show windows on female consumers' shopping behaviour, Journal of Consumer Marketing, 31 (5), 380-390.

[13] Jones, P. , Comfort, D. , Clarke-Hill, C. , Hillier, D. (2010) Retail experience stores: experiencing the brand at first hand, Marketing Intelligence \& Planning, 28 (3), 241-248.

[14] Kerfoot, S. , Davies, B. , Ward, P. (2003) Visual merchandising and the creation of discernible retail brands, International Journal of Retail \& Distribution Management, 31 (3), 143-152. 
[15] Kiran, P. , Mridula, S. (2015) Study of visual merchandising and customer needs in visual merchandising for a toys store, Advances in Management, 8 (5), 17-21.

[16] Law, D. , Wong, C. , Yip, J. (2012) How does visual merchandising affect consumer affective response?: An intimate apparel experience, European Journal of Marketing, 46 (1/2), 112-133.

[17] Levy, M. , Weitz, B. A. (2007) Retailing Management, New York: McGraw-Hill / Irwin

[18] Mohan, G. , Sivakumaran, B. , Sharma, P. (2013) Impact of store environment on impulse buying behavior, European Journal of Marketing, 47 (10), 1711-1732.

[19] Mower, J. M. , Kim, M. , Childs, M. L. (2012) Exterior atmospherics and consumer behavior: Influence of landscaping and window display, Journal of Fashion Marketing and Management: An International Journal, 16 (4), 442-453.

[20] Mrvica Mađarac, S. , Stojanović, S. (2009) Space management in the function of sales increase (original language: Croatian). Master Thesis. Vukovar: Polytechnic School Lavoslav Ružička.

[21] Narayan, G. , Chandra, R. (2015) Factors Affecting the Purchase of Food and Grocery Products from Modern Retail Stores: An Empirical Study, The IUP Journal of Management Research, 14 (2), 7-23.

[22] Oliver, S. (2014) Apple Store design and layout can be trademarked in Europe, court rules. Appleinsider. com [online]. July 10, 2014. Available at: http://appleinsider. com/articles/14/07/10/apple-store-design-and-layoutcan-be-trademarked-in-europe-court-rules (accessed February 4, 2016)

[23] Parsons, A. G. (2011) Atmosphere in fashion stores: do you need to change?, Journal of Fashion Marketing and Management: An International Journal, 15 (4), 428-445.

[24] Pearsall, J. , Hanks, P. , eds. (1999) New Oxford Dictionary of English, 3rd ed. Oxford: Oxford University Press

[25] Smith, P. , Burns, D. J. (1996) Atmospherics and retail environments: the case of the "power aisle", International Journal of Retail \& Distribution Management, 24 (1), 7-14.

[26] Soars, B. (2003) What every retailer should know about the way into the shopper's head, International Journal of Retail \& Distribution Management, 31 (12), 628-637.

[27] Stahlberg, M. , Maila, V. (2010) Shopper Marketing: How to Increase Purchase Decisions at the Point of Sale, Philadelphia: Kogan Page

[28] Underwood, B. , Moore, B. S. , Rosenhan, D. L. (1973) Affect and self-gratification, Developmental Psychology, 8 (2), 209-214.

[29] Vučijak, B. (2007) Multi-criterion optimisation in space management (original language: Croatian), Prostor: znanstveni časopis za arhitekturu i urbanizam, 15 (33), 109-117.

[30] Waters, S. (n/a) Types of Store Layouts, RetailAbout. com [online]. Available at: http://retail. about. com/od/storedesign/ss/store_layouts. htm\#showall (accessed February 3, 2016)

Table 1. Sample characteristics $(\mathrm{N}=199)$

\begin{tabular}{|l|l|}
\hline Sample characteristics & Percentage \\
\hline Gender & \\
Male & 29.6 \\
Female & 70.4 \\
\hline Age & \\
Under 18 & 7.5 \\
$19-30$ & 37.7 \\
$31-45$ & 30.2 \\
$46-60$ & 23.1 \\
61 and higher & 1.5 \\
\hline
\end{tabular}




\begin{tabular}{|l|l|}
\hline Working status & \\
Employed & 73.9 \\
Unemployed & 7.5 \\
Student & 20.1 \\
Retiree & 1.5 \\
Other & 4.5 \\
\hline
\end{tabular}

Table 2. Rank of importance of store choice factors

\begin{tabular}{|c|c|c|c|c|c|c|}
\hline \multirow[b]{2}{*}{$\begin{array}{l}\text { Rank of } \\
\text { importance }\end{array}$} & \multicolumn{6}{|c|}{ Percentage distribution } \\
\hline & Price & Service quality & Store design & $\begin{array}{l}\text { Merchandise } \\
\text { quality }\end{array}$ & $\begin{array}{l}\text { Store location } \\
\text { (proximity) }\end{array}$ & Working hours \\
\hline 1 & 35.2 & 27.1 & 8.0 & 44.7 & 18.1 & 12.6 \\
\hline 2 & 20.1 & 20.1 & 18.1 & 20.6 & 22.6 & 15.1 \\
\hline 3 & 8.5 & 13.1 & 21.6 & 7.0 & 18.1 & 19.1 \\
\hline 4 & 9.5 & 10.1 & 17.6 & 4.0 & 7.5 & 12.6 \\
\hline 5 & 9.0 & 8.0 & 13.6 & 4.0 & 14.1 & 16.1 \\
\hline 6 & 9.0 & 12.1 & 15.6 & 8.5 & 8.1 & 13.0 \\
\hline 7 & 8.5 & 9.5 & 5.5 & 14.1 & 11.6 & 11.6 \\
\hline
\end{tabular}

Table 3. Assessment of importance of store attributes

\begin{tabular}{|l|l|l|}
\hline Store attribute & $\begin{array}{l}\text { Average assessment of } \\
\text { importance }\end{array}$ & Rank \\
\hline Aesthetic design of the store & 3.40 & 8 \\
\hline Cleanliness of shopping carts and baskets & 3.71 & 5 \\
\hline Store cleanliness & 4.44 & 2 \\
\hline Hassle-free movement space around cashiers & 3.53 & 7 \\
\hline Pleasant music and lighting & 3.21 & 10 \\
\hline Layout that allows practical traffic flow & 3.87 & 4 \\
\hline Clearly displayed merchandise prices & 4.48 & 1 \\
\hline Aisle width & 3.62 & 6 \\
\hline Visibility of presented merchandise & 3.97 & 3 \\
\hline Shelf height & 3.30 & 9 \\
\hline Presentation of new products on hot spots in the store & 3.17 & 11 \\
\hline
\end{tabular}

Table 4. Assessment of irritation by negative store attributes

\begin{tabular}{|l|l|l|}
\hline Negative store attribute & Average assessment of irritation & Rank \\
\hline Impolite store personnel & 4.67 & 1 \\
\hline Uninformed and uneducated store personnel & 4.26 & 3 \\
\hline Crowd in the store & 3.97 & 4 \\
\hline Loud music & 3.55 & 9 \\
\hline Long waiting lines at cashiers & 3.80 & 7 \\
\hline Unattractive design & 3.96 & 5 \\
\hline Poor visibility of merchandise price & 4.37 & 2 \\
\hline Too high shelves & 3.41 & 10 \\
\hline Layout that does not allow practical traffic flow & 3.63 & 8 \\
\hline No parking & 3.90 & 6 \\
\hline
\end{tabular}


Figure 1. Mean assessments of negative store attributes by age groups
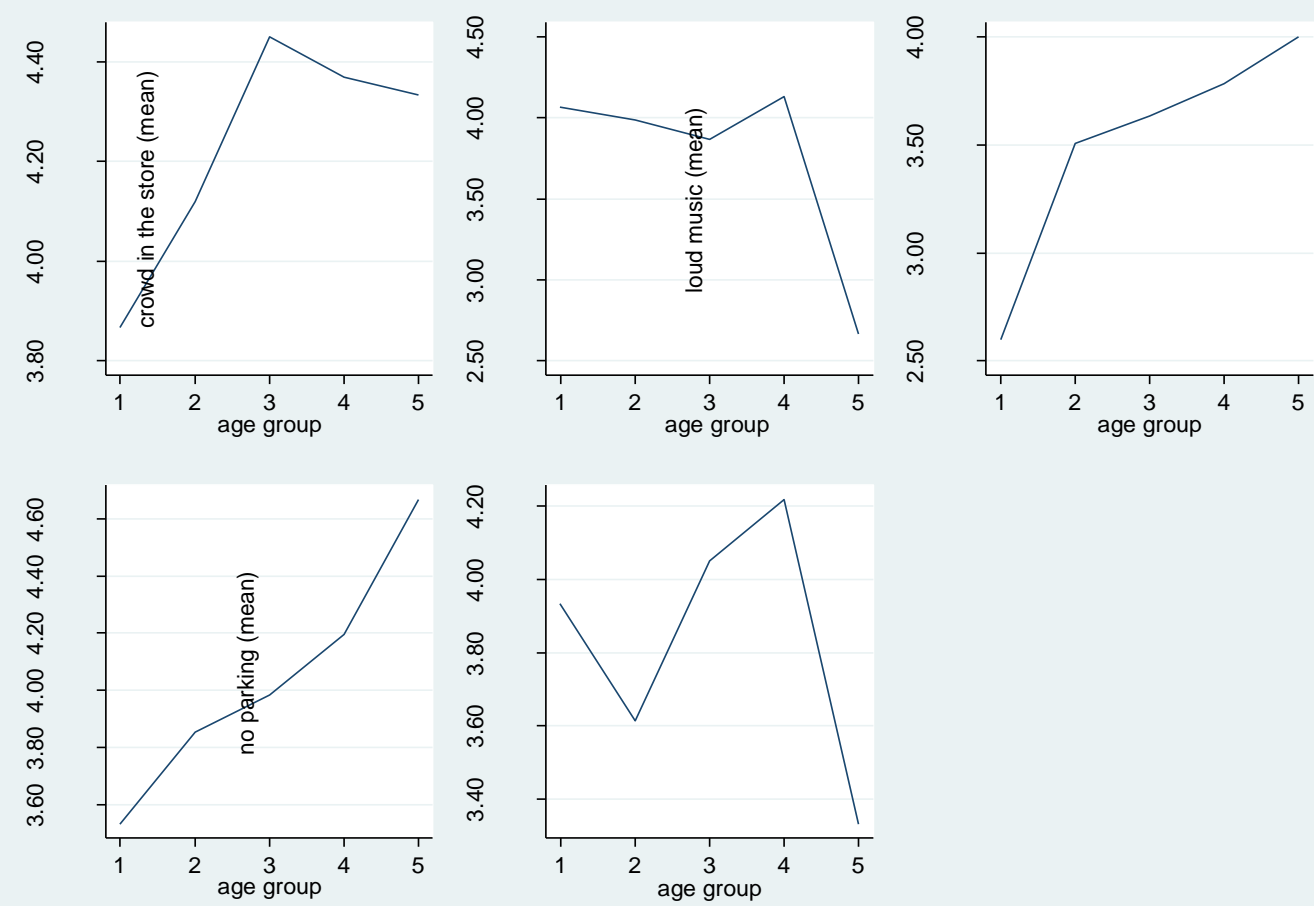

Note: Age groups: 1 = under 18, $2=18-30,3=31-45,4=46-60,5=61$ and higher

Figure 2. Mean assessments of negative store attributes by customers' working status
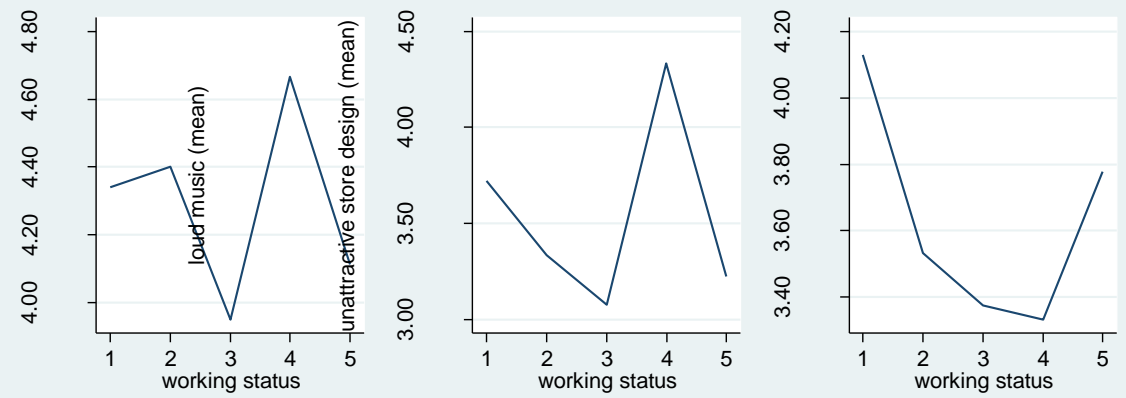

Note: Working status: 1 = employed, 2 = unemployed, $3=$ student, 4 = retiree, 5 = other

Appendix: Supermarket layout schemes 


\section{Layout 1}

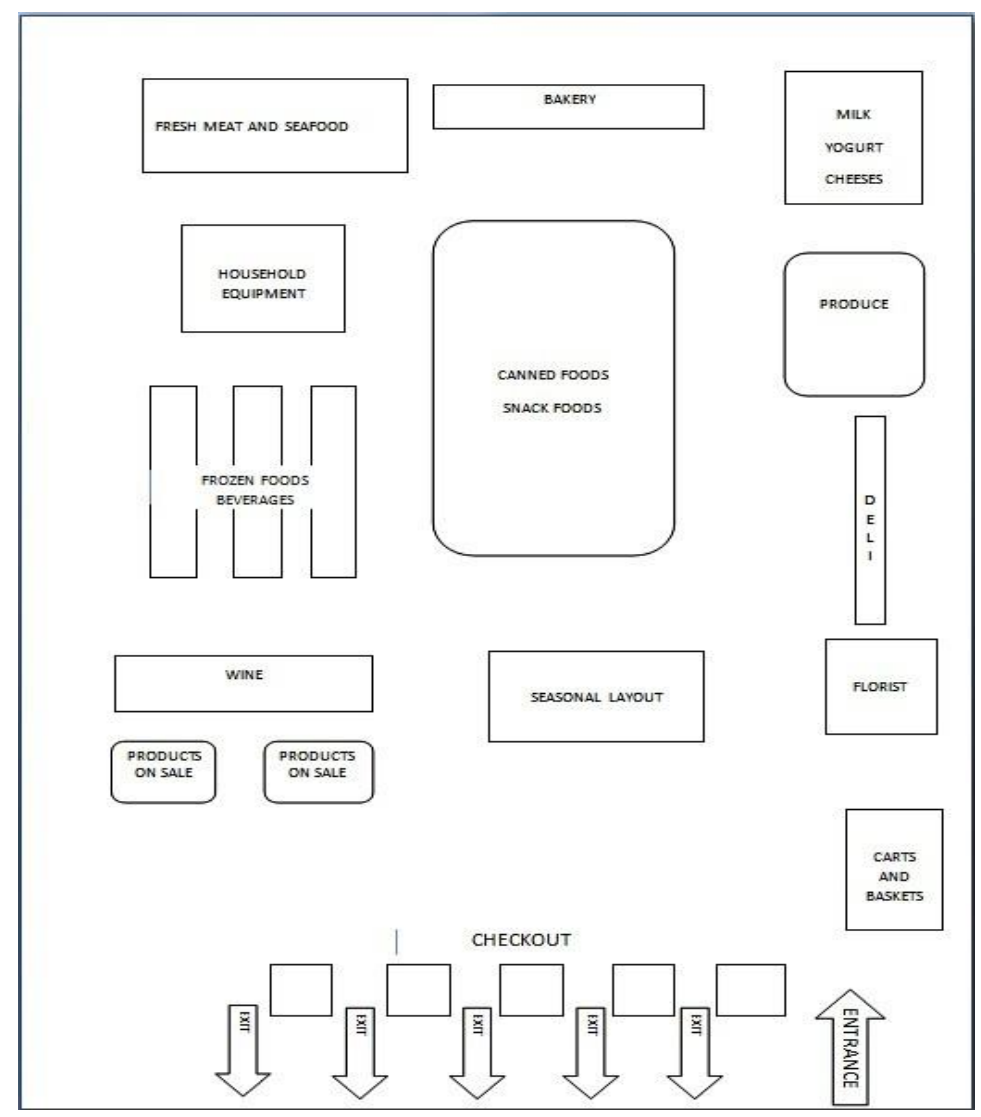

Layout 2 


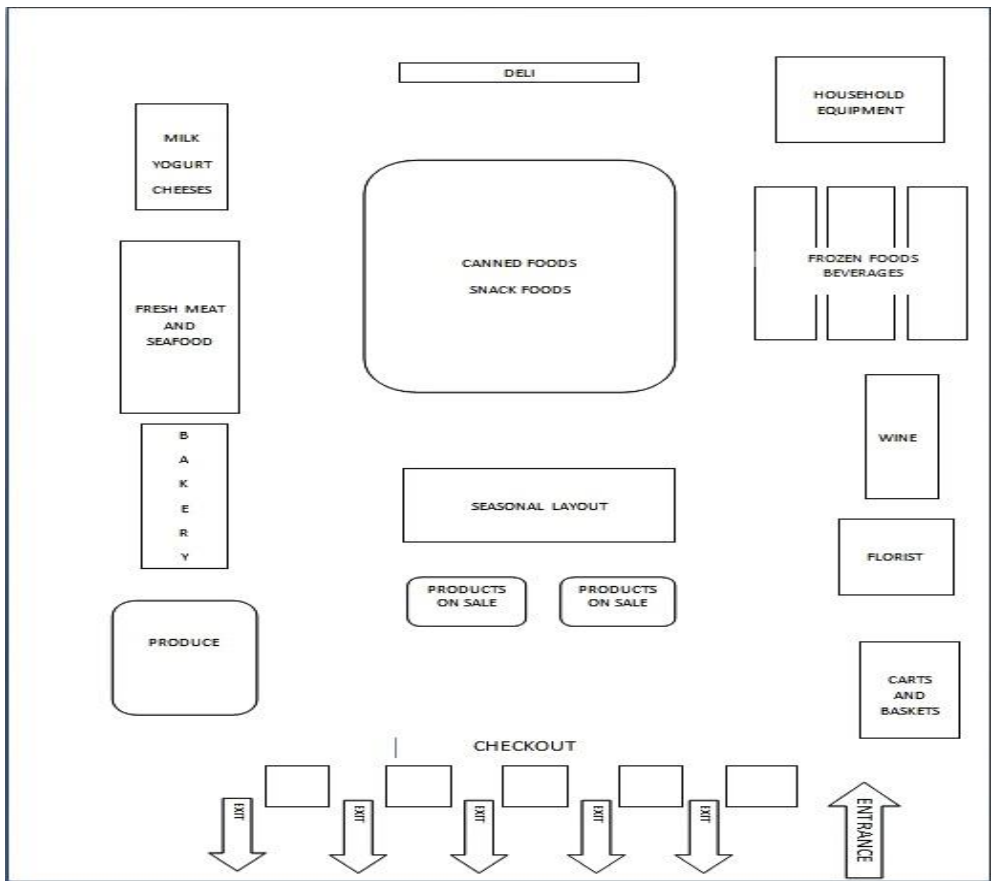

Layout 3

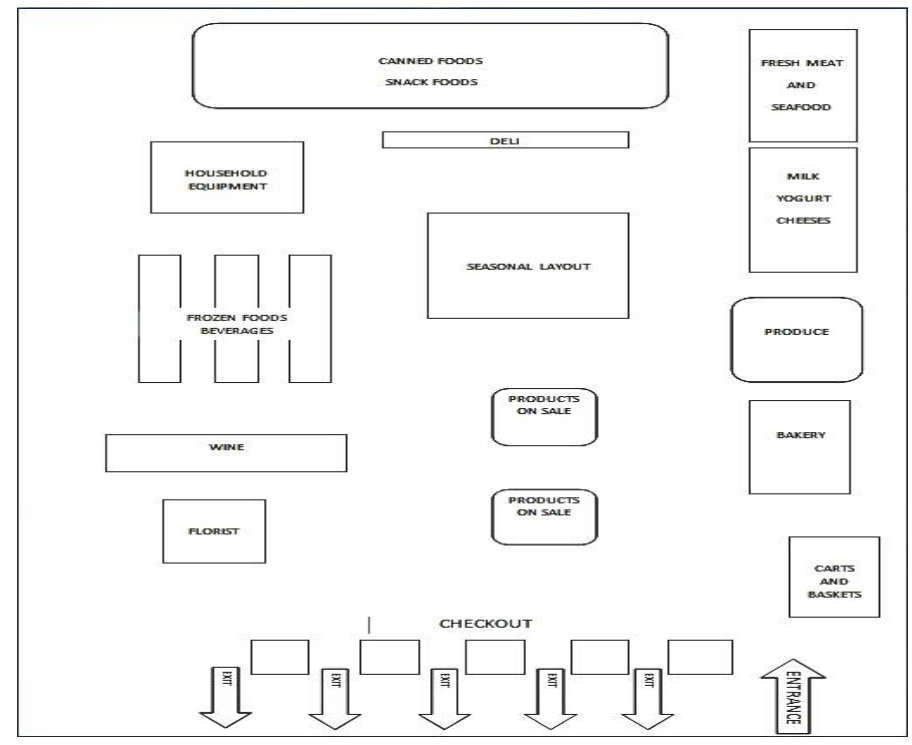

